\title{
Lise Son Sınıf Öğrencilerinde Riskli Sağlık Davranışları ve Algılanan Sosyal Destek İlişkisi
}

The Relationship between Risky Health Behaviors and Perceived Social Support in Final Year High School Students

\author{
Murat SEMERCI ${ }^{1}$, Rabia HACIHASANOĞLU AȘILAR ${ }^{2}$
}

\begin{abstract}
ÖZ
Ergenlik döneminde birçok sağlık riski davranışı ortaya çıkmakta, genellikle yetişkinlik süresince devam etmekte ve yaşam boyu iyilik halini ve sağlı̆g 1 etkilemektedir. $\mathrm{Bu}$ araştırma lise son sınıf öğrencilerinde riskli sağlık davranışları ve algılanan sosyal destek ilişkisini belirlemek amacı ile yapılmıştır. Tanımlayıcı ilişki arayıcı nitelikte olan araştırmanın evrenini Gümüşhane il merkezinde eğitim veren liselerin son sinıf öğrencileri $(\mathrm{N}=904)$ oluşturmuş̧tur. Araştırmada örneklem seçimine gidilmemiş, araştırmaya alma ölçütlerini karşılayan tüm öğrencilere ulaşılması hedeflenmiş ve 609 (evrenin \%67,37'si) öğrenci çalışma kapsamına alınmıştır. Araştırmanın verileri Aralık 2014-Ocak 2015 tarihleri arasında Tanımlayıcı Soru Formu, Riskli Sağlık Davranışları Ölçeği (RSDÖ) ve Algılanan Sosyal Destek Ölçeği Revizyonu (ASDÖR) ile sınıf ortamında araştırmacı tarafindan toplanmıştır. Öğrencilerin yaş ortalaması $17,28 \pm 0,67$ 'dir. RSDÖ toplam puan ortalamas1 $64,51 \pm 10,81$ ve ASDÖ-R toplam puan ortalaması $122,36 \pm 15,16$ olarak belirlenmiştir. Sosyal destek azaldıkça riskli sağlık davranışlarının arttığı, öğrencilerin RSDÖ toplam puan ortalamasına göre riskte oldukları, ASDÖ-R puan ortalamasına göre ise algılanan sosyal desteğin yüksek olduğu söylenebilir. Ailelere ve öğretmenlere riskli sağlık davranışlarını önleme ve sosyal desteği artırmaya yönelik danışmanlık hizmetlerinin verilmesi önerilmektedir.
\end{abstract}

Anahtar Kelimeler: Ergen, Okul sağlığı hemşiresi, Riskli sağlık davranışları, Sosyal destek.

\begin{abstract}
A variety of risky health behaviors are adopted in adolescence; they usually prevail through adulthood and affect well-being and health throughout life. This study was conducted to determine the relationship between risky health behaviors and perceived social support in final year high school students. The population of this descriptive correlational study consisted of final year students ( $\mathrm{N}=904)$ of the high schools providing education in the city of Gümüşhane. No sampling was attempted and 609 students $(67.37 \%$ of the population) who met the inclusion criteria were included in the study. The study data were collected between December 2014 and January 2015 by the investigator in classroom setting using a Descriptive Questionnaire, the Risky Health Behaviors Scale (RHBS) and the Revised Perceived Social Support Scale (PSSS-R). The mean age of the students was 17.28 \pm 0.67 . The mean total RHBS score was $64.51 \pm 10.81$ and the mean total PSSS-R score $122.36 \pm 15.16$. The results of the study suggest that social support decreases with increasing risky health behaviors, the students were at risk according to their mean total RHBS score and the perceived social support was high according to their mean total PSSS$\mathrm{R}$ score. Provision of consultancy services to families and teachers is recommended to improve their skills in preventing risky health behaviors and promoting social support.
\end{abstract}

Keywords: Adolescent, Risky health behaviors, School health nurse, Social support.

*Bu çalışma 2016 yllında Erzincan Üniversitesi Sağlık Bilimleri Enstitüsü Hemşirelik Anabilim Dalında yüksek lisans tezi olarak kabul edilmiş, 28-30 Nisan 2017 th World Conference on Health Sciences (HSCI-2017) kongresinde sözel bildiri olarak sunulmuştur.

${ }^{1}$ Araştırma Görevlisi, Gümüşhane Üniversitesi Sağlık Bilimleri Fakültesi Hemşirelik Bölümü, muratsemerci90@gmail.com, ORCID:00000002-0840-7134

${ }^{2}$ Prf. Dr. Yalova Üniversitesi Sağlık Bilimleri Fakültesi Hemşirelik Bölümü, Halk Sağlığı Hemşireliği ABD, rabia_hhoglu@hotmail.com, ORCID:0000-0002-7371-3883

İletişim / Corresponding Author:

Murat SEMERCI

Geliş Tarihi / Received:

31.01 .2020

e-posta/e-mail:

muratsemerci90@gmail.com

Kabul Tarihi/Accepted:

27.08 .2020 


\section{GíRiş}

Ergenlik, fiziksel ve duygusal süreçlerin neden olduğu, cinsel ve ruhsal toplumsal olgunlaşma ile başlayıp, bireyin bağımsızlığını, kimlik duygusunu ve toplumsal üretkenliğini kazandığında sonlanan bir dönemdir. ${ }^{1} \mathrm{Bu}$ dönemde gencin düşünme yetisinde önemli gelişmeler olur, sağlık davranışları şekillenmeye ve seçeceği meslekle ilgili düşünceler oluşmaya başlar. ${ }^{2}$ Ayrıca bu dönem çelişkilerin yaşandığı, sorgulamadan risk alındığ 1 bir dönemdir. ${ }^{3}$ Ergenlik döneminde birçok sağlık riski davranışı ortaya çıkmakta genellikle yetişkinlik süresince devam etmekte ve yaşam boyu iyilik halini ve sağllğ etkilemektedir. ${ }^{4}$ Risk kavramı ergenlerin sağlığını ve iyilik halini tehdit eden bir etkene maruz kalma üzerine yapılanmıştır. Risk davranışlarına karşı önlem alınmazsa kazalar, sigara, alkollü içki ve uyuşturucu madde kullanımı, beslenme bozukluğu, cinsel yolla bulaşan hastalıklar, şiddet davranış1, intihar gibi birçok problem yaşanabilmektedir. ${ }^{5}$ Çocukluktan erişkinliğe adım atan ergen davranışlarında, günlük aktivitelerinde, alışkanlıklarında değişimler yaşamakla birlikte çeşitli sağlık problemleri ile de karşı karşıya kalmaktadır. ${ }^{3}$ Birçok davranışın olumlu veya olumsuz olarak ergenin sağlığını, riskli sağlık davranışlarının da birbirlerini etkilediği, alkol ve uyuşturucu madde kullanımının kazalara ve bunun sonucunda yaralanma ve ölümlere yol açtığı ve ergenlerin ruhsal sağlığını olumsuz etkilediği bilinmektedir. ${ }^{5}$ Gençlik İstatistikleri 2018 y1l raporuna göre gençlerin \%33,6' sının anormal kiloda olduğu, 21,4'ünün sigara kullandığı, 9,3'ünün alkol kullandığ1, yaşa göre intihar hızının yüz binde 5,3 olduğu bildirilmiştir. ${ }^{6}$

Ergenin riskli davranışları göstermesinde veya bu davranışlardan korunmasında sosyal desteğin önemli etkileri bulunduğu bilinmektedir. $^{7}$ Aile, arkadaş ve öğretmenlerin ergenlerin besin seçme davranışlarını etkilediği ve ergenlerin sağlıklı beslenme konusunda yeterli bilgiye sahip olmadıkları bildirilmiştir. ${ }^{8}$ Ergenler genellikle aile dışından birisi ile istek, sorun ve endișelerini paylaşmak istediğinde onlara olanak verilmeli, problemlerini ve isteklerini kolayca ifade etmeleri sağlanmalıdır. ${ }^{2}$ Sosyal desteğin ergenlerde olumlu etkileri bilinmektedir. Bunlar: Ergenin iyi bir kimlik gelişimi göstermesi, özgüveninin artması daha fazla sorumluluk alabilmesi, okul başarısında artış, sigara, alkol ve uyuşturucu madde kullanımının azalması, kalıplaşmış olumsuz düşüncelerin olmaması, endişe ve depresyon oranlarının azalması, daha az suç işleme, daha az okul devamsızlığına ve sağlık sorunlarında azalmaya katkı sağlamadır.' Ergenlerin sağlığını geliştirmede güvenli bir ortamın sağlanması, beslenme, bulașıc1 hastalıklardan ve kazalardan korunma gibi konularda sağlık eğitimi ve sağlık danışmanlığı hizmetleri sunularak, olumlu sağlık davranışları kazandırma ile fiziksel ve ruhsal sağlık iyileştirilebilir ve sosyal yeterlilik, sorumluluk, okul başarısı ve toplumsal ilișki arrtırılabilir. ${ }^{10}$ Ergen sağlık davranışlarını etkileyen faktörler hakkında artan bilgi, halk sağlığı hemşirelerinin ve diğer sağlık profesyonellerinin aileler ve topluluklardaki gençlerin sağlığını etkileyen gelişimsel ve yaşam tarzı faktörlerine daha duyarlı olmaları için çok önemlidir. ${ }^{11}$ Uygun müdahale programlarının uygulanmasına ek olarak, gençlerin olumsuz etkilere maruz kalmalarını azaltmak ve olumlu gelişmeyi destekleyen faaliyetlere katılma firsatlarını arttırmak için adımlar atılması gereklidir. ${ }^{4}$

$\mathrm{Bu}$ çalışma lise son sınıf öğrencilerinde riskli sağlık davranışları ve algılanan sosyal destek ilișkisini belirlemek amacı ile yapılmıştır. Ayrıca öğrencilerin riskli sağlık davranışları ve algılanan sosyal destek düzeyleri nedir? ve öğrencilerin tanımlayıcı özellikleri riskli sağlık davranışları ve algilanan sosyal destek düzeylerini etkiler mi? sorularına da yanıt aranmıştır. 


\section{MATERYAL VE METOT}

Tanımlayıcı ilişki arayıcı nitelikte olan bu çalışmanın evrenini Gümüşhane il merkezinde bulunan liselerin son sinif öğrencileri $\quad(\mathrm{N}=904) \quad$ oluşturmuştur. Araştırmada örnekleme seçimine gidilmemiştir. Verilerin toplandığı tarihte okulda olma, 18 yaş ve altında olan öğrencilerin ailelerinden izin alınmış olma ölçütlerini karşılayan 609 (evrenin \%67,36's1) öğrenci araştırmanın örneklemini oluşturmuştur. Veriler Aralık 2014-Ocak 2015 tarihleri arasında tanımlayıc1 soru formu, Riskli Sağlık Davranışları Ölçeği ve Algılanan Sosyal Destek Ölçeği Revizyonu olmak üzere üç form kullanılarak araştırmacı tarafindan sınıf ortamında toplanmış ve formların öğrenciler tarafından doldurulması ortalama olarak 20-25 dakikada tamamlanmıştır. Gümüşhane il merkezinde toplam 11 tane lise bulunmaktadır. $\mathrm{Bu}$ liselerin bir tanesinden çalışma izni alınamadığından ve bir lisenin de sağlık meslek lisesi olması nedeni ile araștırma kapsamı dışında bırakılmış ve çalışma dokuz lisede yapılmıştır.

\section{Tanımlayıcı Soru Formu}

Öğrencileri tanımlayan (yaş, cinsiyet, aile tipi, başarı durumu algısı gibi) 15 sorudan oluşmuştur.

\section{Riskli Sağlık Davranışları Ölçeği (RSDÖ)}

Gençlerin riskli sağlık davranışlarını belirlemek amaciyla Çimen ve Savaşer (2003) tarafından geliştirilmiştir. Likert tipi beşli olan ölçek Psikososyal, Beslenme, Fiziksel Aktivite, Hijyen ve Madde kullanımı olmak üzere beș alt boyuttan ve 35 maddeden oluşmaktadır. Ölçek maddelerinden 1, 2, 4, $5,6,7,8,10,12,14,15,16,17,18,19,22$, 23, 25. maddeleri tersine çevrilmekte, diğerleri aynen alınmakta ve 35 . madde herhangi bir alt boyuta girmediğinden toplam ham puan 34-170 arasında değişmektedir. Ölçek toplam ham puanı mutlak değer cinsinden 100'e çevrilerek 20-100 arasında ölçek puanı elde edilmektedir. Puanın yüksek olması kişilerin sağlık davranışları yönünden riskte olduğunu, düşük olması ise sağlık davranışlarının iyi olduğunu göstermektedir. RSDÖ toplam için Cronbach alfa değeri 0,86, Beslenme 0,75, Fiziksel Aktivite 0,52, Psikososyal 0,75, Hijyen 0,65 ve Madde Kullanımı alt boyutu 0,60 olarak bildirilmiştir. ${ }^{12} \mathrm{Bu}$ çalışmada RSDÖ toplam Cronbach alfa değeri 0,77, Beslenme 0,71, Psikososyal 0,62, Hijyen 0,72 ve Madde Kullanımı alt boyutu 0,75 olarak bulunmuştur. Fiziksel Aktivite alt boyutu Cronbach alfa değeri 0,33 çıtı̆̆ 1 için alt boyut olarak kullanılmamış ancak toplam ölçek puanının hesaplanmasında kullanılmıştır.

\section{Algılanan Sosyal Destek Ölçeğinin Revizyonu (ASDÖ-R)}

Öğrencilerin ailesinden, arkadaş ve öğretmeninden aldığı sosyal desteği belirlemek amaciyla Yıldırım tarafindan geliştirilmiş ve 2004 yılında revizyonu yapılmıştır. ASDÖ-R her bir durum cümlesi Aile, Arkadaş ve Öğretmen Desteği olmak üzere üç alt boyutta toplam 50 soru ile yanıtlanmaktadır. Likert tipi üçlü derecelendirme içeren ölçekte toplam puan 50-150 arasında değişmekte, yüksek puan kişinin daha fazla sosyal destek aldığ1 anlamına gelmektedir. ASDÖ-R için Cronbach alfa değeri 0,93, AID için 0,94, ARD için 0,91, ÖĞD için 0,93 olarak bildirilmiştir. ${ }^{13} \mathrm{Bu}$ çalışmada ASDÖ-R için alfa değeri 0,92 , AİD için 0,89 , ARD için 0,88 ve ÖĞD için 0,93 olarak bulunmuştur.

\section{Verilerin Analizi}

Verilerin normal dağılıma uygunluğu Shapiro-Wilk testi ile değerlendirilmiş ve verilerin normal dağılıma uygun olmadığ1 görülmüştür. Verilerin analizinde tanımlayıcı özellikler sayı, yüzdelik, en az ve en çok değerler ortalama ve standart sapma ve veriler normal dağılım göstermediğinden ortanca (\%25-75) olarak verilmiştir. Kruskal Wallis $\mathrm{H}$ testi ve Mann Whitney-U testi ve ileri analiz olarak Mann Whitney-U testi kullanılmıştır. RSDÖ ile ASDÖ-R puan ortalaması arasındaki ilişkiyi belirlemede Sperman korelasyon ve ölçeklerin 
güvenilirliğini belirlemede Cronbach alfa analizi kullanılmıştır. İstatistiksel analizler SPSS (Statistical Package for Social Science) programı 15.0 sürümü kullanılarak yapılmış ve anlamlılık düzeyi $\mathrm{p}<0,05$ olarak kabul edilmiştir.

\section{Araştırmanın Etik Yönü}

Araştırmaya başlamadan önce Erzincan Üniversitesi Etik Kurul onay1 (08/12/2014 tarih ve 44495147/188 sayıl1), Gümüşhane İl Milli Eğitim Müdürlüğünden yazılı izin (11/12/2014 tarih ve 77146347/604/6370419 sayılı) ilgili liselerin müdürlüklerinden sözlü izin, 18 yaşını doldurmayan öğrencilerin ailelerinden yazılı izin ve tüm öğrencilere çalışmanın amacı ve yöntemi anlatılarak çalışmaya katılmaya gönüllü olanlardan sözel/yazılı izin alınmıştır. Ayrıca RSDÖ ve ASDÖ-R'nin araştırmada kullanılabilmesi için ölçek sahiplerinden yazılı izin alınmıştır.

\section{Araştırmanın Sınırlılıkları}

Araştırmanın lise son sınıf öğrencilerinde yapılmış olması nedeni ile sınıf düzeyinde karşılaştırma yapılamaması ve araştırma sonuçlarının yalnızca araştırma grubuna genellenebilmesi araştırmanın birinci, RSDÖ fiziksel alt boyutunun değerlendirilememesi ise ikinci sınırlılığı olarak belirlenmiştir.

\section{BULGULAR VE TARTIŞMA}

Öğrencilerin \%53,7'si erkek, \%56,8'inin başarı ve \%62,2'sinin ailesinin ekonomik durumunu orta olarak algıladığ 1 , \%88'inin gelir getiren bir işte çalışmadığ 1 bulunmuştur. Ögrencilerin \%53,5'inin babasının ortaokul/lise mezunu olduğu, \%44,8'inin kendini bazen mutlu hissettiği \%61,1'inin sağlığını iyi ve \%44,3'ünün annesinin, \%32,5'inin babasının kendisini yetiştirmedeki tutumunu koruyucu olarak algıladığ 1 ve \%93,6'sının kronik hastalığ1 olmadığı belirlenmiştir (Tablo 2,3). Öğrencilerin \%86,9'unun çekirdek aileye sahip, 56,6'sının annesinin okuryazar/ilkokul mezunu, \%95,6'sının anne ve babasının hayatta olduğu, \%61,6'sının ailesi ile birlikte evde yaşadığı ve yaş ortalamalarının $17,28 \pm 0,67$ olduğu belirlenmiştir.

Tablo 1. RSDÖ ve ASDÖ-R Alt Boyutlar ve Toplam Puan Ortalamalarının Dağılımı

\begin{tabular}{lrrrr}
\hline $\begin{array}{l}\text { Ölçekler ve alt } \\
\text { boyutlar }\end{array}$ & $\begin{array}{c}\text { Madde } \\
\text { Sayısı }\end{array}$ & Alt ve üst değer & $\begin{array}{c}\text { Alınan alt ve üst } \\
\text { değer }\end{array}$ & \multicolumn{1}{c}{ Ort \pm SS } \\
\hline Psikososyal & 10 & $20-100$ & $21,74-100,00$ & $47,48 \pm 13,14$ \\
Beslenme & 11 & $20-100$ & $25,00-100,00$ & $60,94 \pm 11,68$ \\
Hijyen & 4 & $20-100$ & $20,00-100,00$ & $32,05 \pm 12,89$ \\
Madde kullanımı & 5 & $20-100$ & $20,00-100,00$ & $29,81 \pm 16,28$ \\
\hline RSDÖ Toplam* & 34 & $20-100$ & $36,97-100,00$ & $64,51 \pm 10,81$ \\
\hline AİD & 20 & $20-60$ & $20-60$ & $51,67 \pm 6,44$ \\
ARD & 13 & $13-39$ & $13-39$ & $32,99 \pm 5,24$ \\
ÖĞD & 17 & $17-51$ & $17-51$ & $37,69 \pm 8,76$ \\
\hline ASDÖ-R Toplam & 50 & $50-150$ & $50-150$ & $122,36 \pm 15,16$ \\
\hline
\end{tabular}

*Fiziksel aktivite alt boyutu değerlendirmeye alınmamıştır.

Öğrencilerin RSDÖ toplam puan ortalaması $64,51 \pm 10,81$ olup, en yüksek puan ortalamasinı beslenme $60,94 \pm 11,68$, en düşük puan ortalamasını madde kullanımı $29,81 \pm 16,28$ alt boyutundan aldikları, psikososyal ve hijyen alt boyutları puan ortalamasının sirasiyla $47,48 \pm 13,14$; $32,05 \pm 12,89$ olduğu belirlenmiştir (Tablo 1 ). Öğrencilerin ölçekten alınabilecek değerlere göre riskte olduğu, özellikle beslenme ve psikososyal açıdan bu riskin arttığ söylenebilir. $\mathrm{Bu}$ sonuç öğrencilerin riskli sağlık davranışları düzeyi nedir sorusunu yanıtlamaktadır. Aynı ölçek kullanılarak lise ögrencileri ile yapılan bir çalışmada bu çalışmadan daha düşük değerler bildirilmiş, RSDÖ toplam puan ortalaması $43,80 \pm 7,52$, beslenme $50,97 \pm 8,43$, psikososyal $46,50 \pm 13,24$, hijyen $29,15 \pm 15,03$ ve madde kullanımı puan ortalamasi 27,95 $\pm 12,38$ olarak belirtilmiştir. ${ }^{14}$ Lise öğrencileri ile yapılan diğer bir çalışmada da ergenlerin ergen 
risk alma ölçeği puanına göre \%48,5'inin riskli grupta olduğu bildirilmiştir. ${ }^{15}$ Sonuçta bireysel, bölgesel ve kültürel özelliklerin etkili olabileceği düşünülmektedir.

Adölesanların ASDÖ-R toplam puan ortalamas1 122,36 $\pm 15,16$, Aile 51,67 $\pm 6,44$, Arkadaş $32,99 \pm 5,24$ ve Öğretmen desteği alt boyutu için puan ortalamasının 37,69 $\pm 8,76$ olduğu belirlenmiştir (Tablo 1). Ölçek değerlerine göre öğrencilerin ASDÖ-R toplam, aile ve arkadaş desteği puanlarının yüksek, öğretmen desteği puanının ise orta düzeyin üzerinde olduğu söylenebilir. $\mathrm{Bu}$ sonuç öğrencilerin algılanan sosyal sosyal destek düzeyi nedir sorusunu yanitlamaktadır Adölesanlarla aynı ölçek kullanılarak yapılan bir çalışmada da benzer sonuçlar bildirilmiş olup ASDÖ-R Aile alt boyutu için puan ortalamasının 53,62 $\pm 7,21$ Arkadaş için $35,33 \pm 4,65$ ve Öğretmen desteği için $39,27 \pm 9,22$ olarak bulunmuştur. ${ }^{16}$

Tablo 2. Öğrencilerin Tanımlayıcı Özelliklerine Göre RSDÖ Alt Boyutlar ve Toplam Puanlarının Karşılaştırılması ( $(\mathrm{s}=609)$

\begin{tabular}{|c|c|c|c|c|c|c|c|}
\hline $\begin{array}{l}\text { Tanımlayıcı } \\
\text { özellikler }\end{array}$ & $\mathbf{S}$ & $\%$ & $\begin{array}{r}\text { Psikososyal } \\
\text { Ort (\%25-75) } \\
\end{array}$ & $\begin{array}{r}\text { Beslenme } \\
\text { Ort (\% 25-75) }\end{array}$ & $\begin{array}{r}\text { Hijyen } \\
\text { Ort (\%25-75) }\end{array}$ & $\begin{array}{r}\text { Madde } \\
\text { kullanımı } \\
\text { Ort }(\% 25-75) \\
\end{array}$ & $\begin{array}{r}\text { RSDÖ } \\
\text { Ort (\% 25-75) }\end{array}$ \\
\hline \multicolumn{8}{|l|}{ Cinsiyet } \\
\hline $\mathrm{K} 1 \mathrm{z}$ & 282 & 46,3 & $41,3(34,7-47,8)$ & $62,5(54,1-70,8)$ & $24(20-32)$ & $20(20-20)$ & $61,3(54,6-68)$ \\
\hline Erkek & 327 & 53,7 & $50,(41,3-60,8)$ & $60,4(52-66,6)$ & $32(28-40)$ & $25(20-40)$ & $63,8(57,9-73,9)$ \\
\hline \multirow[t]{2}{*}{ Test ve önemlilik } & & & $\mathrm{U}=25555,500$ & $\mathrm{U}=42004,000$ & $\mathrm{U}=28232,000$ & $\mathrm{U}=29320,000$ & $\mathrm{U}=34003,000$ \\
\hline & & & $\mathrm{p}<0,001$ & $\mathrm{p}=0,580$ & $\mathrm{p}<\mathbf{0 , 0 0 1}$ & $\mathrm{p}<\mathbf{0 , 0 0 1}$ & $\mathrm{p}<\mathbf{0 , 0 0 1}$ \\
\hline \multicolumn{8}{|c|}{ Başarı durumunu algılama } \\
\hline İyi & 224 & 36,8 & $45,6(36,9-54,3)$ & $58,3(52-68,7)$ & $28(20-36)$ & $20(20-30)$ & $61,3(54,6-69,7)$ \\
\hline Orta & 346 & 56,8 & $45,6(36,9-54,3)$ & $60,4(52-68,7)$ & $28(24-36)$ & $20,0(20-35)$ & $63(56,5-71,4)$ \\
\hline Kötü & 39 & 6,4 & $50(39,1-60,8)$ & $64,5(58,8-70,8)$ & $36(28-44)$ & $30,0(20-43,7)$ & $71,4(63-81,7)$ \\
\hline Test ve önemlilik & & & 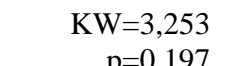 & $\begin{array}{r}\mathrm{KW}=9,022 \\
\mathbf{n}=\mathbf{0 . 0 1 1} *\end{array}$ & $\mathrm{KW}=21,158$ & $\mathrm{KW}=5,531$ & $\mathrm{KW}=23,506$ \\
\hline \multicolumn{8}{|c|}{ Ailesinin ekonomik durumunu algılama } \\
\hline İyi & 200 & 32,9 & $47,8(36,9-56,5)$ & $60,4(52-66,6)$ & $28(20-36)$ & $20(20-32,5)$ & $62,1(55,4-71,4)$ \\
\hline Orta & 379 & 62,2 & $43,4(36,9-54,3)$ & $60,4(52-68,7)$ & $28(24-36)$ & $20(20-35)$ & $62,1(57,1-69,7)$ \\
\hline Kötü & 30 & 4,9 & $54,3(44-61,9)$ & $64,5(57,8-72,9)$ & $34(32-41)$ & $30(20-46,2)$ & $71,4(62,3-79,2)$ \\
\hline Test ve önemlilik & & & $\begin{array}{r}\mathrm{KW}=7,227 \\
\mathbf{p}=\mathbf{0 , 0 2 7} *\end{array}$ & $\begin{array}{r}\mathrm{KW}=4,6651 \\
\mathrm{p}=0,098\end{array}$ & $\begin{array}{r}K W=20,075 \\
\mathbf{p}<\mathbf{0 , 0 0 1}\end{array}$ & $\begin{array}{r}\mathrm{KW}=10,843 \\
\mathbf{p}=\mathbf{0 , 0 0 4} * *\end{array}$ & $\begin{array}{r}\mathrm{KW}=12,949 \\
\mathbf{p}=\mathbf{0 , 0 0 2} * *\end{array}$ \\
\hline \multicolumn{8}{|c|}{ Gelir getiren işte çalışma durumu } \\
\hline Çalışıyor & 73 & 12,0 & $52,1(43,4-63)$ & $58,3(50-64,5)$ & $28(24-44)$ & $30,0(20-40)$ & $64,7(55,4-75,6)$ \\
\hline Çalışmıyor & 536 & 88,0 & $43,4(36,9-54,3)$ & $60,4(52-68,7)$ & $28(24-36)$ & $20,0(20-30)$ & $62,1(56,3-70,5)$ \\
\hline Test ve önemlilik & & & $\mathrm{U}=13849,000$ & $\mathrm{U}=17386,500$ & $\mathrm{U}=17964,000$ & $\mathrm{U}=15870,500$ & $\mathrm{U}=17529,000$ \\
\hline & & & $\mathbf{p}<0,001$ & $\mathrm{p}=0,122$ & $\mathrm{p}=0,251$ & $\mathbf{p}=\mathbf{0 , 0 0 3} * *$ & $\mathrm{p}=0,149$ \\
\hline \multicolumn{8}{|c|}{ Baba eğitim durumu } \\
\hline Okuryazar değil & 12 & 2,0 & $52,1(37,5-71,7)$ & $65,6(55,2-75)$ & $26(20-52)$ & $35(20-65)$ & $75,2(58,4-84,8)$ \\
\hline Okuryazar/İlkokul & 163 & 26,8 & $43,4(36,9-56,5)$ & $60,4(54,1-66,6)$ & $32(24-36)$ & $20(20-35)$ & $63,8(57,1-71,4)$ \\
\hline Ortaokul/Lise & 326 & 53,5 & $47,8(36,9-56,5)$ & $61,4(52-70,8)$ & $28(24-36)$ & $20(20-35)$ & $63(57,1-72,2)$ \\
\hline Üniversite ve $\uparrow$ & 108 & 17,7 & $41,3(36,9-50)$ & $58,3(52-64,5)$ & $28(20-32)$ & $20(20-30)$ & $59,2(53,7-68,4)$ \\
\hline Test ve önemlilik & & & $\begin{array}{r}\mathrm{KW}=9,778 \\
\mathbf{p}=\mathbf{0 , 0 2 1} *\end{array}$ & $\begin{array}{r}\mathrm{KW}=6,202 \\
\mathrm{p}=0,102\end{array}$ & $\begin{array}{r}\mathrm{KW}=3,667 \\
\mathrm{p}=0,299\end{array}$ & $\begin{array}{r}\mathrm{KW}=4,920 \\
\mathrm{p}=0,178\end{array}$ & $\begin{array}{r}\mathrm{KW}=14,735 \\
\mathbf{p}=\mathbf{0 , 0 0 2} * *\end{array}$ \\
\hline \multicolumn{8}{|c|}{ Genel olarak kendini mutlu hissetme durumu } \\
\hline Evet & 253 & 41,6 & $43,4(36,9-52,1)$ & $56,2(50-64,5)$ & $28(20-36)$, & $20(20-30)$ & $59,6(54,4-66,3)$ \\
\hline Hayır & 83 & 13,6 & $50,0(41,3-60,8)$ & $64,5(52-70,8)$ & $32(24-40)$ & $30(20-45)$ & $69,7(59,6-78,9)$ \\
\hline Bazen & 273 & 44,8 & $47,8(36,9-56,5)$ & $62,5(54,1-70,8)$ & $28(24-40)$ & $20,(20-35)$ & $64,7(58,8-72,2)$ \\
\hline Test ve önemlilik & & & $\mathrm{KW}=15,503$ & $\mathrm{KW}=27,010$ & $\mathrm{KW}=9,830$ & $\mathrm{KW}=19,567$ & $\mathrm{KW}=45,286$ \\
\hline & & & $\mathrm{p}<0,001$ & $\mathrm{p}<\mathbf{0 , 0 0 1}$ & $\mathrm{p}=0,007 * *$ & $\mathrm{p}<\mathbf{0 , 0 0 1}$ & $\mathrm{p}<\mathbf{0 , 0 0 1}$ \\
\hline \multicolumn{8}{|l|}{ Sağlığını algılama } \\
\hline İyi & 372 & 61,1 & $44,5(36,9-54,3)$ & $58,3(52-64,5)$ & $28(24,0-36,0)$ & $20(20-30)$ & $61,3(55,4-68,9)$ \\
\hline Orta & 206 & 33,8 & $47,8(36,9-56,5)$ & $64,5(54,1-70,8)$ & $28(24,0-40,0)$ & $20(20-40)$ & $65,9(57,9-73,9)$ \\
\hline Kötü & 31 & 5,1 & $50,0(39,1-57,6)$ & $64,5(56,2-75,0)$ & $32(26,0-40,0)$ & $30(20-40)$ & $69,7(60,9-79,8)$ \\
\hline Test ve önemlilik & & & $\mathrm{KW}=3,590$ & $\mathrm{KW}=23,980$ & $\mathrm{KW}=5,385$ & $\mathrm{KW}=10,964$ & $K W=27,957$ \\
\hline & & & $\mathrm{p}=0,166$ & $\mathrm{p}<0,001$ & $\mathrm{p}=0,068$ & $\mathbf{p}=0,004 * *$ & $\mathrm{p}<\mathbf{0 , 0 0 1}$ \\
\hline
\end{tabular}


alt boyutunda ise farkın önemli olmadığ

$\mathrm{Bu}$ çalışmada erkek öğrencilerin RSDÖ psikososyal, hijyen, madde kullanımı alt boyut ve toplam puanları kız öğrencilerden anlamlı düzeyde yüksek $(\mathrm{p}<0,001)$, beslenme alt boyutunda ise anlamlı bir fark olmadiğ 1 $(p>0,05)$; diğer bir ifade ile erkek öğrencilerin beslenme dişında sağlik davranışları yönünden riskte olduğu bulunmuştur. Aynı ölçek kullanılarak lise öğrencileri ile yapılan bir çalışmada RSDÖ psikososyal, hijyen ve madde kullanımı ve toplam puanının erkeklerde kızlardan, beslenme alt boyutunda ise kizların erkeklerden anlamlı düzeyde düşük puana sahip olduğu bulunmuştur. ${ }^{17}$ Lise öğrencileri ile yapılan diğer çalışmalarda da erkek öğrencilerin RSDÖ ve Riskli Davranış Ölçeği puanlarının kız öğrencilerden anlamlı düzeyde yüksek olduğu belirtilmiştir. ${ }^{14,18}$ Bildirilen çalışma sonuçları ile bu çalışma sonucunu benzerlik göstermektedir.

Başarı durumunu algılamaya göre RSDÖ toplam $(p<0,001)$, beslenme $(p<0,05)$ ve hijyen alt boyut puanları arasinda farkın önemli olduğu $(p<0,001)$, psikososyal ve madde kullanımı ile önemli bir fark olmadığı belirlenmiştir $\quad(p>0,05)$. Beslenme alt boyutunda farkın başarı durumunu kötü olarak öğrencilerin riskli sağlık davranışları düzeyinin en yüksek, hijyen alt boyutu ve RSDÖ toplamında ise tüm grupların birbirinden farklı olmasından kaynaklandığ 1 belirlenmiştir. Benzer şekilde aynı ölçek kullanılarak lise öğrencileri ile yapılan bir çalışmada okul başarısını iyi olarak algılayan öğrencilerin kötü ve orta olarak algılayan öğrencilerden RSDÖ toplam puanı anlamlı olarak yüksek bulunmuştur. ${ }^{17}$ Diğer bir çalışmada başarı durumunu iyi olarak algılayan, düzenli olarak ders çalışan öğrencilerin sigara ve alkol kullanım oranları önemli düzeyde düşük bulunmuştur. ${ }^{19}$ Karne notu 3,5'dan düşük olan öğrencilerin, 3,5'dan fazla olanlara göre kuraldışı davranış puanlarının anlamlı olarak yüksek olduğu diğer bir çalışma bulgusudur. ${ }^{20}$

Ailesinin ekonomik durumunu algilama ile RSDÖ toplam, psikososyal, hijyen ve madde kullanımı alt boyut puanları arasında anlamlı bir fark olduğu $(p<0,001)$, beslenme belirlenmiştir $\quad(p>0,05)$. Farkın RSDÖ toplam, psikososyal ve madde kullanımı alt boyut için kötü algılayan grubun riskli sağlık davranışları puanının en yüksek, hijyen için tüm grupların birbirinden farklı olmasından kaynaklandığ 1 belirlenmiştir. Lise öğrencileri ile yapılan bir çalışmada sosyo-ekonomik düzeyi kötü olanların motosiklete binerken kask kullanmama, emniyet kemeri kullanmama, sigara satın alma ve yaşam boyu kullanma oranlarının arttığ1 bildirilmiştir. $^{21}$ Mevcut çalışma sonucunda öğrencilerin beklentileri, hayata bakışı gibi birçok faktörün etkili olabileceği düşünülmektedir.

Gelir getiren bir işte çalışanların psikososyal ve madde kullanımı alt boyut puanlarının gelir getiren bir işte çalışmayanlara göre önemli düzeyde daha yüksek olduğu( $p<0,001)$, çalışma durumuna göre RSDÖ toplam, beslenme ve hijyen alt boyut puanları arasında önemli bir fark olmadığı belirlenmiştir $(p>0,05)$. Üniversite öğrencileri ile yapılan bir çalışmada gelir getiren bir işte çalışan öğrencilerin çalışmayanlardan sağlıklı yaşam biçimi davranışları toplam, beslenme, sağlık sorumluluğu, egzersiz alt boyut puanlarının anlamlı düzeyde daha yüksek, kişilerarası destek, kendini gerçekleştirme ve stres yönetimi alt boyutları ile anlamlı bir fark belirlenmemiştir. ${ }^{22}$ Mevcut çalışma sonucu paraya ulaşmanın imkânları arttırarak bazı riskli sağlık davranışlarının oluşmasında risk oluşturabileceğini düşündürmektedir.

Baba eğitim durumuna göre RSDÖ toplam ve psikososyal alt boyut puanı arasında önemli bir fark olduğu $(p<0,05)$, beslenme, hijyen ve madde kullanımı alt boyutları ile önemli bir fark olmadığ belirlenmiştir $(p>0,05)$. Farkın psikososyal alt boyutu için ortaokul/lise ile üniversite ve üzeri mezunu arasında, RSDÖ toplam da ise üniversite ve üzeri mezunlarından kaynaklandığ ile babası üniversite mezunu olan öğrencilerin toplam riskli sağlık davranış düzeyleri en düşüktür. Ortaöğretimde okuyan öğrencilerle yapılan bir çalışmada baba 
eğitim seviyesi lise ve üzeri olanların, ortaöğretim ve altı olanlardan sağlığ geliştirici davranışları toplam puan ortalamalarının anlamlı düzeyde daha yüksek olduğu belirlenmiştir. ${ }^{23}$. Eğitim düzeyi yüksek babaların sağlıklı davranış bilincini kazandırmada rol model oldukları, bu durumun da öğrencilerin riskli sağlık davranışları üzerinde olumlu etkisi olabileceği ile açıklanabilir.

Genel olarak kendini mutlu hissetme durumuna göre RSDÖ toplam ve tüm alt boyut puanları arasında önemli düzeyde bir fark saptanmıştır $(p<0,001)$. Yapılan ileri analizde riskli sağlık davranışları toplam, psikososyal ve madde kullanımı boyutlarında, genel olarak kendini mutlu hisseden öğrencilerin riskli sağlık davranışları düzeyinin en düşük, kendini mutlu hissetmeyen öğrencilerin en yüksek ve tüm grupların birbirilerinden farklı olduğu belirlenmiştir. Beslenme ve hijyen boyutlarında kendini mutlu hisseden öğrencilerin riskli sağlık davranışları düzeyi en düşük olarak bulunmuştur. Lise öğrencileri ile yapılan bir çalışmada toplumsal konum ile ilgili yüksek düzeyde risk alan öğrencilerin öznel iyi oluş puanları, orta ve düşük düzeyde risk alan öğrencilerden daha düşük olduğu bildirilmiştir. ${ }^{24} \mathrm{Bu}$ çalışma sonucu, kendini mutlu hissetme gibi olumlu duygularm, ergenlerde riskli davranışlara karşı koruyucu etki yapması ile açıklanabilir.

Sağlık durumunu algılamaya göre RSDÖ beslenme, madde kullanımı ve toplam puanı arasında önemli bir fark bulunurken $(p<0,001)$, psikososyal ve hijyen alt boyutu puanları arasında fark belirlenmemiştir (p>0,05). Farkın sağlık durumunu iyi olarak algilayan öğrencilerin kötü ve orta algılayanlara göre riskli sağlık davranışları puanlarının önemli düzeyde düşük olmasından kaynaklandığı belirlenmiştir (Tablo 2). Lise öğrencileri ile yapılan çalışmalarda da benzer şekilde sağlığını çok iyi algılayan öğrencilerin en düşük RSDÖ puanına sahip olduğu bildirilmiştir. ${ }^{14,17}$ Hoyt ve arkadaşlarının (2012) çalışmasında adölesanlık boyunca olumlu iyilik halinin, genç yetişkinlikte sağlığın genel olarak iyi algılanmasına ve daha az riskli davranışlara neden olduğu bildirilmiştir. ${ }^{25}$

Öğrencilerin aile tipi, anne-babanın hayatta olma durumu, anne eğitim durumu, annesinin ve babanın kendisini yetiştirme tutumunu algılama, kalınan yer ve kronik bir hastalığa sahip olma durumuna göre RSDÖ tüm alt boyut ve toplam puanları arasında önemli bir fark belirlenmemiştir $(p>0,05)$. Benzer şekilde lise öğrencileri ile yapılan çalışmalarda aile tipine göre öğrencilerin kuraldışı davranış puanlarının farklılaşmadığı belirtilmiştir. ${ }^{20}$ Anne eğitim durumuna göre ögrencilerin sigara ve alkol kullanım oranının farklılaşmadiğı; ebeveynin kendisini yetiştirme tutumuna göre alkol tüketimi bakımından farklılık olmadığı; demokratik tutum sahibi ebeveyni olan öğrencilerin, baskılayıc1, disiplinsiz ve tutarsiz ebeveyne sahip öğrencilere göre daha az sigara tükettikleri bildirilmiştir. ${ }^{19}$ Anne ve babanın sağ olup olmaması ve eğitim durumları ile öğrencilerin çok yüksek şiddet eğilimi arasında anlamlı bir fark olmadığ bildirilmiştir. ${ }^{26}$ Yurtta ya da evde kalmanın sigara ve alkol kullanımında anlamlı bir farklılık oluşturmadığı diğer bir çalışma bulgusudur. ${ }^{19}$ Adölesanlarla yapılan bir çalışmada da bu çalışma sonucundan farklı olarak kronik bir sağlı durumu olan gençlerin günlük sigara içme, mevcut esrar kullanıcıları olma ve şiddet içeren veya antisosyal eylemler gerçekleştirme ve 3 veya $\geq 4$ riskli davranış bildirme olasılığının sağlıklı bireylerden daha yüksek olduğu bildirmiştir. $^{27} \mathrm{Bu}$ farklllıkta bireysel ve kültürel özelliklerin yanı sıra, hastalığın öneminin algılayış biçimlerinin etkili olabileceği düşünülmektedir. 
Tablo 3. Öğrencilerin Tanımlayıcı Özelliklerine Göre ASDÖ-R Alt Boyutlar ve Toplam Puanlarının Karşılaştırılması

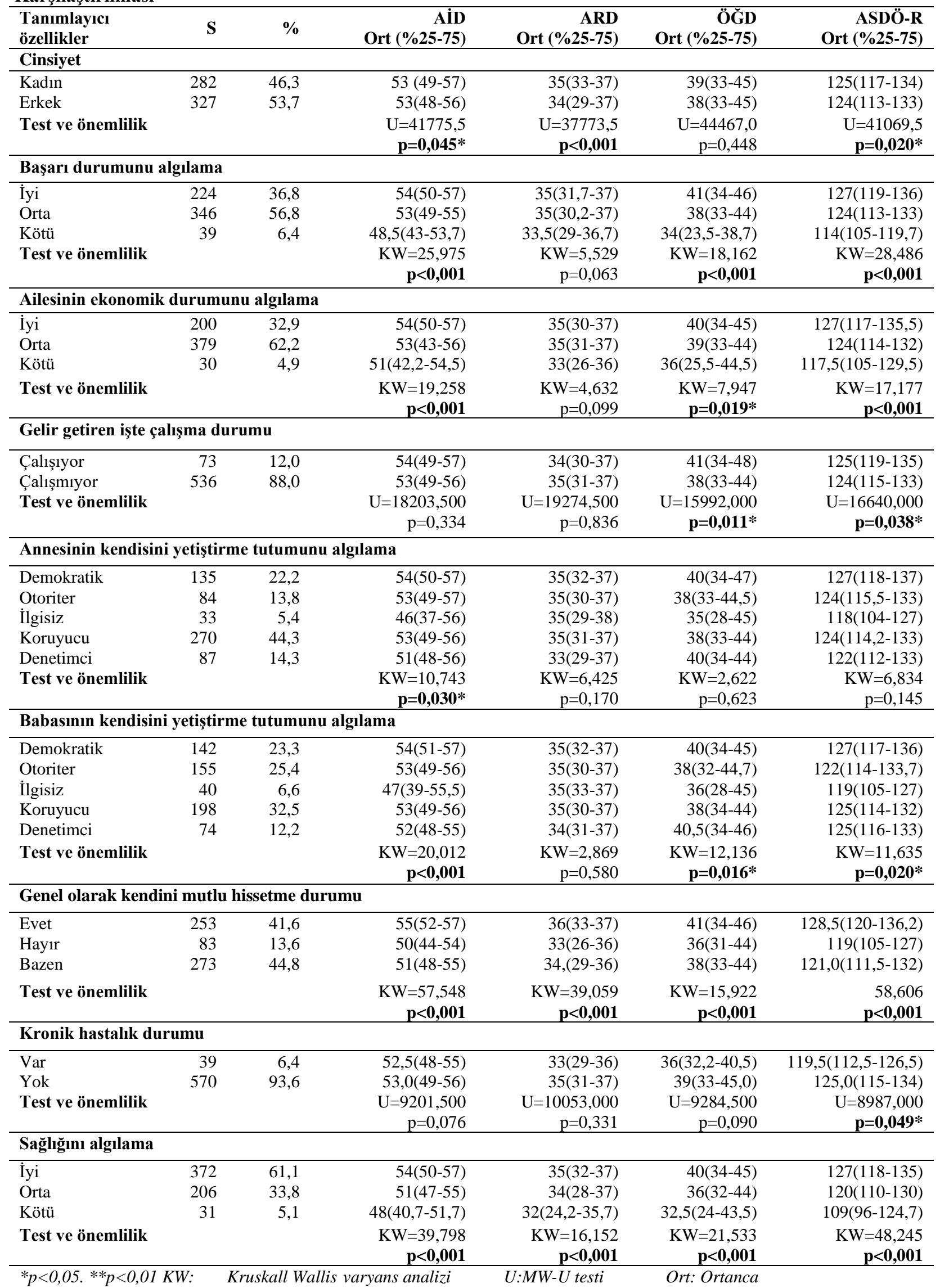


K1z öğrencilerin ASDÖ-R toplam, aile ve arkadaş desteği alt boyutlar puanının erkeklere göre önemli düzeyde yüksek olduğu $(p<0,05, p<0,001)$, cinsiyete göre öğretmen desteği puanının farklılaşmadığı saptanmıştır $(p>0,05)$. Lise öğrencileri ile yapılan bir çalışmada da kız öğrencilerin ASDÖ-R toplam ve aileden algıdıkları sosyal destek puan ortlamalarının erkeklerden anlamlı düzeyde yüksek olduğu, cinsiyete göre arkadaş ve öğretmen destek puanının farklılaşmadığı belirtilmiştir. ${ }^{28}$ Mevcut çalışma bildirilen çalışma sonucu ile arkadaş boyutu dişında benzerlik göstermektedir. $\mathrm{Bu}$ çalışmada kız öğrencilerin sosyal destek algısının erkek öğrencilerden yüksek olması, kadınların erkeklere göre sosyal destek kaynaklarının daha çok farkında olmaları; duygu, düşünce ve sorunlarını daha fazla paylaşmaları ve daha fazla yardım alabildikleri ile açıklanabilir.

Başarı durumunu algılamaya göre ASDÖ$\mathrm{R}$ aile, öğretmen desteği alt boyut ve toplam puanları arasında önemli bir fark olduğu $(\mathrm{p}<0,001)$, arkadaş desteği ile fark olmadığ saptanmıştır $(p>0,05)$. İleri analizde aile desteğinin başarı durumunu iyi olarak algılayan öğrencilerde en yüksek olduğu görülmüştür. Yanı sıra öğretmen ve toplam sosyal desteğin, başarı durumunu iyi olarak algılayan öğrencilerde en yüksek, başarı durumunu kötü olarak algılayanlarda ise en düşük ve tüm grupların birbirinden farklı olduğu saptanmıştır. Bu çalışma sonuçlarına benzer olarak lise son sınıf öğrencilerinin aile ve öğretmen desteğinin akademik başarıyı olumlu bir şekilde etkilediği belirtilmiştir. ${ }^{29}$

Ailesinin ekonomik durumunu algilama ile ASDÖ-R aile, öğretmen desteği alt boyut ve toplam puanları arasında önemli fark olduğu $(p<0,05)$, arkadaş desteği ile fark olmadığı belirlenmiştir( $p>0,05)$. Farkın aile desteği ve toplam için tüm grupların birbirinden farklı, öğretmen desteği için kötü algılayan grubunun en düşük, iyi algılayan grubun en yüksek puana sahip olmasından kaynaklandığı belirlenmiştir. $\mathrm{Bu}$ çalışma sonucunda farklı olarak üniversite öğrencileri ile yapılan çalışmalarda ekonomik durum ile sosyal destek arasında önemli bir fark bildirilmemiştir. ${ }^{30,31} \mathrm{Bu}$ farklılıkta bölgesel ve kültürel farklılıkların etkili olabileceği düşünülmektedir.

Çalışan öğrencilerin ASDÖ-R öğretmen desteği ve toplam puanının çalışmayan öğrencilerden önemli düzeyde yüksek $(\mathrm{p}<0,05)$, çalışma durumuna göre aile ve arkadaş desteği puanı arasında ise önemli bir fark olmadığı saptanmıştır $(\mathrm{p}>0,05)$. Yapılan bir çalışmada çalışma durumu ile arkadaş, akran ve diğer otoritelerden aldiğ 1 sosyal destek sıklığı arasında bir farklılık olmadığı, ancak çalışan öğrencilerin otorite figürlerinden daha fazla destek beklediği bildirilmektedir. ${ }^{32}$ Mevcut çalışma sonucu öğrencilerin okul yaşamı dışında çalışma ortamında sosyal bağlar kurma ve bu ortam ilişkilerini destekleyici bulma olasılıklarını düşündürmektedir.

Annesinin kendisini yetiştirme tutumunu algılama ile aile desteği arasındaki fark önemli bulunmuştur(p<0,05). Diğer alt boyutlar ve toplamda ise annesinin kendisini yetiştirme tutumunu algılama durumuna göre bir fark bulunmamıştır. İleri analizde farkın annesinin kendisini ilgisiz bir tutumla yetiştirdiğini algılayan öğrencilerin aile desteğinin anlamlı olarak düşük; ayrıca annesinin kendisini demokratik tutumla yetiştirdiğini algılayanların, kendisinin denetimci bir tutumla yetiştirildiğini algılayanlardan anlamlı olarak yüksek düzeyde aile desteği algısı belirlenmiştir. (p>0,05). Ailesi ile ilişkileri iyi olan üniversite öğrencilerinin, ilişkilerinin orta düzeyde olduğunu belirten öğrencilere göre aile desteğinin anlamlı olarak yüksek olduğu belirtilmiştir ${ }^{33}$

Babasının kendisini yetiştirmedeki tutumunu algilama ile aile ve öğretmen desteği alt boyut ve toplam puanı arasında önemli fark olduğu $(p<0,05)$, arkadaş desteği ile fark olmadiğ 1 belirlenmiştir $(p>0,05)$. İleri analizde aile desteği algısı babasını ilgisiz algılayan öğrencilerin en düşük; babasını demokratik algılayanların, denetimci ve otoriter algilayanlardan anlamlı olarak yüksek olduğu belirlenmiştir. Öğretmen desteği algısı babasını denetimci 

$\begin{array}{lll}\text { algılayan öğrencilerin en düşük; babasını } & \begin{array}{c}\text { otoriter } \\ \text { demokratik algılayanların, }\end{array}\end{array}$ algılayanlardan anlamlı olarak yüksek olduğu belirlenmiştir. Babasını demokratik algilayanların toplam sosyal destek algisı en yüksek; ayrıca babasını denetimci algılayanların ilgisiz algılayanlara göre anlamlı düzeyde yüksek düzeyde sosyal destek alg1s1 bulunmuştur. Üniversite öğrencileri ile yapılan bir çalışmada anne baba tutumunu demokratik olarak algilayan öğrencilerin diğerlerinden (baskıc1, koruyucu, tutarsız) arkadaş ve aileden algıladığ 1 sosyal destek puanlarının anlamlı düzeyde yüksek olduğu, otoriter-baskıcı ebeveynlerin çocukları daha az destek algıladıkları bildirilmiştir. $^{34}$ Bildirilen çalışma sonucu bu çalışma sonucunu destekler niteliktedir. Sonuçta demokratik anne babanın çocuklarına sevgi dolu aynı zamanda denetleyici ve onların ihtiyaçlarını karşılamaya yönelik bir tutum sergilemiş̧ olmalarının etkili olabileceği düşünülmektedir.

Genel olarak kendini mutlu hissetme durumu ile ASDÖ-R tüm alt boyut ve toplam puanları arasında önemli bir fark belirlenmiştir $(p<0,001)$. İleri analizde aile ve toplam sosyal destek düzeyinin genel olarak kendini mutlu hisseden öğrencilerde en yüksek, kendini mutlu hissetmeyenlerde en düşük ve tüm grupların birbirinden farklı olduğu belirlenmiştir. Arkadaş ve öğretmen desteği düzeyleri de kendini mutlu hisseden öğrencilerde en yüksek olarak saptanmıştır. Bir çalışmada öğretmenlerden alınan sosyal desteğin mutluluğu arttırdığı, akran desteği daha az tutarlı olsa da mutlu olduğunu bildiren öğrencilerin mutsuz olanlardan daha fazla destek aldığ 1 bildirilmiştir. ${ }^{35}$ Diğer bir çalışmada mutluluk algısı düşük olanların stres seviyeleri daha yüksek ve diğer insanlarla olan duygusal yakınlığı daha düşük olduğu belirtilmiştir. ${ }^{36}$

Kronik hastalığı olan öğrencilerin olmayan öğrencilere göre önemli düzeyde düșük ASDÖ-R toplam puanına sahip olduğu $(\mathrm{p}<0,05)$, alt boyutlarda ise önemli bir fark olmadiğ 1 belirlenmiştir $\quad(p>0,05)$.
Adölesanlarla yapılan bir çalışmada kronik hastalığ1 olanların, kronik hastalığ1 olmayanlardan algıladıkları arkadaş desteğinin önemli düzeyde düşük olduğu, aileden algilanan sosyal destek bakımından gruplar arasında fark olmadığ bildirilmiştir. ${ }^{37}$ Mevcut çalışma sonucunda hastalığın ciddiyetinin etkili olabileceği düşünülmüştür.

Sağlığını algılama ile ASDÖ-R toplam ve tüm alt boyut puanları arasında önemli bir fark olduğu bulunmuştur $(\mathrm{p}<0,001)$. İleri analizde, sağlığını iyi algılayan ögrencilerin arkadaş desteği düzeyinin en yüksek; aile, öğretmen ve toplam sosyal destek düzeyleri de sağlığını iyi algılayan öğrencilerde en yüksek, kötü algılayanlarda ise en düşük ve tüm grupların birbirinden farklı olduğu bulunmuştur. Adölesanlarla yapılan bir çalışmada algılanan sosyal destek arttıkça sağlik ve iyilik halinin önemli düzeyde arttığ1, stresin azaldığ 1 belirlenmiştir. ${ }^{38} \mathrm{Bu}$ çalışma sonucu bildirilen çalışma sonuçlarını desteklemekte, sosyal desteğin sağlı̆̆1 iyi algılamada yönlendirici bir faktör olabileceği düşünülmektedir.

Öğrencilerin aile tipi, anne-babanın hayatta olma durumu, anne ve babanın eğitim durumu ve kalınan yer ile ASDÖ-R toplam ve alt boyut puanları arasında önemli bir fark olmadığ1 saptanmıştır(p>0,05). Üniversite öğrencileri ile yapılan bir çalışmada algılanan sosyal destek ve aile tipi arasında farkın önemli olmadığı belirtilmiștir. ${ }^{30}$ Diğer bir çalışmada ebeveynlerin sağ olup olmaması ile aile desteği arasında anlamlı bir fark olmadığı, arkadaş desteği ile farkın anlamlı olduğu belirtilmiştir. ${ }^{31}$ Lise öğrencileri ile yapılan bir çalışmada anne ve babanın eğitim durumuna göre aile ve arkadaş desteği arasında önemli bir farkın olmadığı bulunmuştur ${ }^{37}$. Diğger bir çalışmada yurtta kalan öğrencilerin arkadaş ve öğretmen desteği puanlarının aile yanında kalanlardan farklı olmadığ 1 , aile ve algılanan sosyal destek toplam puanının aile yanında kalanlarda anlamlı olarak yüksek olduğu bildirilmiştir. $^{39}$ 
Tablo 4. Öğrencilerin RSDÖ ve ASDÖ-R Alt Boyutları ve Toplam Puan Ortalamaları Arasındaki İlişki

\begin{tabular}{lrrrrrr}
\hline & & Psikososyal & Beslenme & Hijyen & $\begin{array}{r}\text { Madde } \\
\text { kullanımı }\end{array}$ & RSDÖ \\
\hline AIID & $\mathrm{r}$ & $-0,170$ & $-0,215$ & $-0,238$ & $-0,126$ & $-0,268$ \\
& $\mathrm{p}$ & $\mathbf{p}<\mathbf{0 , 0 0 1}$ & $\mathbf{p}<\mathbf{0 , 0 0 1}$ & $\mathbf{p}<\mathbf{0 , 0 0 1}$ & $\mathbf{p = 0 , 0 0 2 *}$ & $\mathbf{p}<\mathbf{0 , 0 0 1}$ \\
ARD & $\mathrm{r}$ & $-0,169$ & $-0,121$ & $-0,180$ & $-0,038$ & $-0,178$ \\
& $\mathrm{p}$ & $\mathbf{p}<\mathbf{0 , 0 0 1}$ & $\mathbf{p}=\mathbf{0 , 0 0 3} *$ & $\mathbf{p}<\mathbf{0 , 0 0 1}$ & $\mathrm{p}=0,352$ & $\mathbf{p}<\mathbf{0 , 0 0 1}$ \\
ÖĞD & $\mathrm{r}$ & $-0,128$ & $-0,159$ & $-0,122$ & $-0,144$ & $-0,192$ \\
& $\mathrm{p}$ & $\mathbf{p}=\mathbf{0 , 0 0 2} *$ & $\mathbf{p}<\mathbf{0 , 0 0 1}$ & $\mathbf{p}=\mathbf{0 , 0 0 3} *$ & $\mathbf{p}<\mathbf{0 , 0 0 1}$ & $\mathbf{p}<\mathbf{0 , 0 0 1}$ \\
ASDÖ-R & $\mathrm{r}$ & $-0,221$ & $-0,246$ & $-0,223$ & $-0,168$ & $-0,316$ \\
& $\mathrm{p}$ & $\mathbf{p}<\mathbf{0 , 0 0 1}$ & $\mathbf{p}<\mathbf{0 , 0 0 1}$ & $\mathbf{p}<\mathbf{0 , 0 0 1}$ & $\mathbf{p}<\mathbf{0 , 0 0 1}$ & $\mathbf{p}<\mathbf{0 , 0 0 1}$ \\
\hline$r_{s}:$ Spearman korelasyon $* p<0,01$ & & & & &
\end{tabular}

Algılanan aile, arkadaş, öğretmen ve toplam sosyal destek arttıkça riskli sağlık davranışlarının anlamlı olarak azaldığı $(\mathrm{p}<0,001)$; algılanan arkadaş desteği ile madde kullanımı arasında anlamlı bir ilişki olmadığı bulunmuştur(p>0,05) (Tablo 4). Kelly ve arkadaşlarının (2011) çalışmasında adölesanların aile ve arkadaştan algıladıkları sosyal destek arttıkça sağlıklı yaşam biçim davranışlarını sürdürme inançlarının anlamlı olarak arttığı ve algılanan zorlukların azaldığ bildirilmiştir. ${ }^{40}$ Lise öğrencileri ile yapılan bir çalışmada da sosyal destek arttıkça riskli davranışlarda azalma bildirilmiştir. ${ }^{41}$ Diğer bir çalışmada aile ve öğretmen desteği arttıkça internet bağımlılığın azaldığı saptanmıştır. $^{42}$ Ortaöğretimde okuyan öğrencilerle yapılan bir çalışmada da yüksek şiddet eğilimi olan öğrencilerde aile, öğretmen ve arkadaş destek düzeylerinin, şiddet eğilimi olmayan öğrencilerden önemli düzeyde düşük olduğu bulunmuştur. ${ }^{43} \mathrm{Bu}$ sonuç bildirilen çalışma sonuçları ile benzerlik göstermektedir. Sosyal destek bireyin yaşam memnuniyetini arttırmada önemli bir faktör ve sağlıklı yașam biçimi davranışı göstermede teşvik edici olabileceği düşünülmektedir.

\section{SONUÇ VE ÖNERILLER}

Öğrencilerin algıladıkları sosyal destek arttıkça riskli sağlık davranışlarının azaldığı, sağlık davranışları açısından riskte oldukları ve algıladıkları sosyal destek düzeylerinin iyi olduğu söylenebilir. Erkek olma, başarı ve ailesinin ekonomik durumunu kötü algılama, çalışıyor olma, baba eğitim düzeyinin düşük olması, genel olarak kendini mutlu hissetmeme ve sağlı̆̆ını kötü algılama RSDÖ bazı alt boyutları ve toplam puanı genel olarak olumsuz yönde etkilediği belirlenmiştir. Kız olma, akademik başarı ve ailesinin ekonomik durumunu iyi olarak algılama, çalışıyor olma, demokratik anne ve baba tutumu, genel olarak kendini mutlu hissetme, kronik hastalığ1 olmama ve sağlığını iyi olarak algılamanın genel olarak ASDÖ-R'yi olumlu yönde etkilediği bulunmuştur. Sosyal destek riskli sağlık davranışlarının oluşumunu engelleyen önemli faktörlerden birisi olduğu için ailelere, öğretmenlere yönelik rehberlik hizmetleri içinde okul sağlığı hemşiresinin yer alması, özellikle riskli sağlık davranışlarını yapmayı tetikleyen faktörler açısından risk altında olan adölesanlarda riskli sağlık davranışlarının oluşmasını önleme ve sosyal desteği artırmaya yönelik eğitim ve danışmanlı hizmetlerinin verilmesi önerilmektedir.

KAYNAKLAR

1. Ergün A., Siş̧man NF. (2016). Ergenlik Dönemi. Gözüm S.(ed). Okul Dönemindeki Çocukların Sağlığının Geliştirilmesi. Ankara: Vize Basın Yayın. 75-85.
2. Yiğit R. (2009). Cocukluk Dönemlerinde Büyüme ve Gelişme. Ankara: Sistem Ofset

3. Nacar M., Günay O. (2011). Adölesan Sağlığı. Öztürk Y., Günay O (ed). Halk Sağlığı Genel Bilgiler. Kayseri: Erciyes Üniversitesi Yayınları. Önder Ofset. 711-750. 
4. Jackson, C. A., Henderson, M., Frank, J. W., \& Haw, S. J. (2012). "An Overview of Prevention of Multiple Risk Behaviour in Adolescence and Young Adulthood'. Journal of Public Health, 34 (suppl 1), i31-i40.

5. Radzik M., Sherer S. (2002). High Risk and Out of Control Behavior. Neinstein LS. (ed). Adolescent Health Care: A Practical Guide Book. Fourth Edition Okdokey. 630-637.

6. Türkiye İstatistik Kurumu (2018). Gençlik İstatistikleri.

7. Sales JM., Charles Irwin E. (2009). Theories of Adolescent Risk Taking: The Biopsychosocial Model. Diclemente RJ., Santelli JS., Crosby RA. (ed). Adolescent Health. Understanding and Preventing Risk Behaviors. USA: Jossey-Bass. $31-41$.

8. Akman M, Tüzün S, Ünalan P.C. "Adolesanlarda Sağlıklı Beslenme ve Fiziksel Aktivite Durumu”. Nobel Med 2012, 8 (1), 24-29.

9. Scales PC., Leffert N. (2004). Developmental Assets: A Synthesis of The Scientific Research on Adolescent Development (2nd edition). Minneapolis, MN, USA: Search Institute

10. Hacıalioğlu N. (2016). Adölesan (ergen) Sağlığı. Erci B. (ed). Halk Sağlığı Hemşireliği. Elâzığ: Anadolu Nobel Tip Kitabevleri. 122-136.

11. Spear, H.J, Kulbok, P.A. (2001). "Adolescent Health Behaviors and Related Factors: a Review'. Public Health Nursing, 18 (2), 82-93.

12. Çimen S., Savaşer S. (2003). "15-18 Yaş Grubu Gençlerde Riskli Sağlık Davranışları Ölçeği'nin geliştirilmesi”. 47. Milli Pediatri Kongresi, 3. Milli Cocuk Hemșireliği Kongresi, 2. Pediatri Asistanları Toplantısı, Bilimsel Program ve Özet Kitabı, İstanbul.

13. Yıldırım İ. (2004). “Algılanan Sosyal Destek Ölçeğinin Revizyonu', Eurasian Journal of Educational Research. 17, 221 236.

14. Tümer A., Şahin S. (2011). "Ergenlerin Riskli Sağlık Davranışları',. Sağlık ve Toplum. (1), 32-38.

15. Akca, S. O., \& Selen, F. (2016). "Erkek Ergenlerde Riskli Davranışlar: Bir lise örneği', TAF Preventive Medicine Bulletin, 15 (3), 206-212.

16. Traş Z., Arslan E. (2013). "Ergenlerde Sosya Yetkinliğin, Algılanan Sosyal Destek Açısından İncelenmesi“* Elementary Education Online, 12 (4), 1133-1140.

17. Geckil, E, Dündar, Ö. (2011). "Turkish Adolescent Health Risk Behaviors and Self- Esteem', Social Behavior and Personality: An İnternational Journal, 39 (2), 219-227.

18. Tuzgöl Dost M., Keklik İ. (2014). "Sürekli Kayg1, Umutsuzluk ve Benlik Saygısının Ergenlerin Riskli Davranısların Yordama Gücü“. Elektronik Sosyal Bilimler Dergisi, 13 (51), 195 208.

19. Hacıhasanoğlu R., Türkleş S., Yıldırım A., Kararkurt P.(2009). "Lise öğrencilerinde Madde Bağımlılığı ve Etkileyen faktörlerin incelenmesi““. Bağımlılık Dergisi. (10),111-123.

20. Aras, Ş., Günay, T., Özan, S. ve Orçın, E. (2007). "İzmir İlinde Lise Öğrencilerinin Riskli Davranışları “. Anatolian Journal of Psychiatry, 8, 186-196.

21. Eneç Can F. (2007). Edirne Sehir Merkezindeki Lise Öğrencilerinde Riskli Sağlık Davranışlarının Değerlendirilmesi. Aile Hekimliği Anabilim Dalı Doktora Tezi, Trakya Üniversitesi, Edirne

22. Tuygar ŞF., Arslan M. (2015). "Sağlık Hizmetleri Meslek Yüksekokulu Öğrencilerinin Sağlıklı Yaşam Biçimi Davranışlarının İncelenmesi“. SDÜ Sağlık Bilimleri Dergisi. 6 (2),59-66.

23. Bebiș H., Akpunar D., Özdemir S., Kılıç S. (2015). "Bir Ortaöğretim Okulundaki Adölesanların Sağlığı Geliştirme Davranıșlarının İncelenmesi“. Gülhane Tıp Dergisi. 57 (2),129-135.
24. Uçan A., Esen Kiran B. (2015). "Ergenlerin Öznel İyi Oluşlarının Toplumsal Konum ile İlgili Risk Alma Değişkenine Göre İncelenmesi“. Mersin Üniversitesi Eğitim Fakültesi Dergisi. 11 (2),289-299.

25. Hoyt LT, Chase-Lansdale PL, McDade TW, Adam EK. (2012). "Positive Youth, Healthy Adults:Does Positive Wellbeing in Adolescence Predict Better Perceived Health and Fewer Risky Health Behaviors in Young Adulthood?". Adolescent Health. 50 (1), 66-73.

26. Bebiş H., Çoşkun S., Açıkel C. ( 2014). "Bir ortaöğretim okulundaki öğrencilerin şiddet eğilim düzeyi ve ilișkili faktörlerin incelenmesi “. Ege Üniversitesi Hemşirelik Fakültesi Dergisi. 30 (1), 1-17.

27. Surís JC, Michaud PA, Akre C, Sawyer SM. (2008) "Health Risk Behaviors in Adolescents with Chronic Conditions". Pediatrics.122 (5), e1113-8

28. Bozgeyikli, H, Doğan, H, Issıklar, A. (2010). "Üstün Yetenekli Öğrencilerin Mesleki Olgunluk Düzeyleri ile Algıladıkları Sosyal Destek Düzeyleri Arasındaki İlişkinin İncelenmesi”. Sosyal Bilimler Enstitüsü Dergisi, 28 (1), 133-149.

29. Yildırım İ., Ergene T. (2003). "Lise Son Sinıf Öğrencilerinin Akademik Başarılarının Yordayıcısı Olarak Sınav Kaygısı, Boyun Eğici Davranışlar ve Sosyal Destek“. Hacettepe Üniversitesi Eğitim Fakültesi Dergisi. 25 (25), 224-234.

30. Y1lmaz E., Y1lmaz E., Karaca F. (2008). "Üniversite Öğrencilerinin Sosyal Destek ve Yalnızlık Düzeylerinin İncelenmesi“. Genel Tip Dergisi. 18 (2), 71-79.

31. Kahriman İ., Yeșilçiçek K. (2007). "Karadeniz Teknik Üniversitesi Trabzon Sağlik Yüksekokulu Öğrencilerinin Aile ve Arkadaşlarından Algıladıkları Sosyal Destek Düzeylerinin Baz Değişkenler Açısından İncelenmesi“. Atatürk Üniversitesi Hemşirelik Yüksekokulu Dergisi. 10 (1),10-21.

32. Markward, M., McMillan, L., \& Markward, N. (2003) "Social Support Among Youth". Children and Youth Services Review, 25 (7), 571-587.

33. Ünsar S., Kurt Sadırlı S., Demir M., Zafer R.,Erol Ö. (2009) "Üniversite Öğrencilerinin Sosyal Destek Düzeyleri ve Etkileyen Etmenler“. Dokuz Eylül Üniversitesi Hemşirelik Yüksekokulu Elektronik Dergisi. 1 (1), 17-29.

34. Çeçen R. (2008). "Öğrencilerinin Cinsiyetlerine ve Anababa Tutum Algılarına Göre Yalnızlık ve Sosyal Destek Düzeylerinin İncelenmesi“. Türk Eğitim Bilimleri Dergisi. 6 (3),415-31

35. Natvig GK, Albrektsen G, Qvarnstrøm U (2003). "Associations between Psychosocial Factors and Happiness Among School Adolescents”. Int J Nurs Pract.9 (3), 166-175.

36. King KA, Vidourek RA, Merianos AL, Singh M. “A Study of Stress, Social Support, and Perceived Happiness Among College Students “. The Journal of Happiness \& Well-Being, 2014, 2 (2), 132-144.

37. Kahriman İ, Polat S. (2003). “Adölesanlarda Aileden ve Arkadaşlardan Algılanan Sosyal Destek ve Benlik Saygısı Arasındaki İlişki”. Anadolu Hemşireik ve Sağlık Bilimleri Dergisi. 6 (2), 13-24.

38. Glozah FN., Pevalin DJ. (2014). "Social Support, Stress, Health, and Academic Success in Ghanaian Adolescents: A Path Analysis". Journal of Adolescence. 37 (4), 451-460.

39. Firat N., Kaya F. (2015). "Yurtta veya Ailesinin Yanında Kalan Öğrencilerin Sosyal Destek Düzeyleri ve Stresle Başa Çıkma Stillerinin İncelenmesi”. Journal of Turkish Studies. 10 (7), 407426.

40. Kelly SA, Melnyk BM, Jacobson DL., O'Haver JA. (2011). "Correlates Among Healthy Lifestyle Cognitive Beliefs, Healthy Lifestyle Choices, Social Support, and Healthy Behaviors in Adolescents: Implications for Behavioral Change Strategies and Future Research". Journal of Pediatric Health Care. 25 (4),216-223. 
41. Gençtanırım D., Ergene T. (2014). "Riskli Davranışlar Ölçeğinin Geliştirilmesi: Geçerlik ve Güvenirlik Çalışmaları". The Journal of Academic Social Science Studies, 25 (1), 125-138.

42. Esen B.N, Gündoğdu M. (2010). "The Relationship between Internet Addiction, Peer Pressure and Perceived Social Support Among Adolescents". The International Journal of Educational Researchers, 2 (1), 29-36

43. Avcı Haskan Ö., Yıldırım İ. (2015). "Ergenlerde Şiddet Eğiliminin Görülme Sıklığı”. Kuramsal Eğitimbilim Dergisi. 8 (1), 106-124. 